\title{
Research on GIS Theory and Practice Teaching Method of Surveying and Mapping Major in University Based on We-Media
}

\author{
Maohua Liu ${ }^{1, a,{ }^{*},}$ Yan Wang ${ }^{1}$, Fang Liu ${ }^{1}$, Di Sha ${ }^{1}$ and Xiubo Sun ${ }^{2}$ \\ ${ }^{1}$ School of Transportation Engineering, Shenyang Jianzhu University, Shenyang, China \\ Liaoning Non-ferrous Geological Exploration Institute, Shenyang, China \\ aarnold0110@sina.com
}

Keyword: We-Media; GIS; Surveying and mapping major; Reform in education

\begin{abstract}
Study on teaching reform methods of GIS in Colleges and universities of Surveying and mapping based on We-Media. From two aspects of theory and practice of GIS course, by means of Micro-blog, WeChat and other media to construct We-Media teaching platform, on the We-Media platform publish courseware, arrange homework, and interact between teachers and students etc. Introduce the We-Media into the classroom of GIS, expand the new form, new space and new field of classroom teaching and practice teaching of GIS course in Colleges and Universities, strengthen the interaction between teachers and students, enhance the interest of teaching, and mobilize the enthusiasm of the students. GIS course based on We-Media platform for college teaching is effective and feasible, and it is also the inevitable trend of college teaching with the development of the times.
\end{abstract}

\section{Introduction}

The concept of We-Media is first proposed by the American scholar Shayne Bowman and Chris Willis. We-Media is a way for ordinary citizens to connect with the global knowledge system through digital technology, a way to provide and share their true views and their own news. With the extensive development of various related research in China, the concept of We-Media is gradually entering the general public field of vision. At present, the generally accepted definition, We-Media is a way and instant communication where an ordinary citizen or organization can access network at any time, any place and in any way through the modern digital technology and the global knowledge system, also, they can provide and share their real opinions, their own news.

In recent years, the development of We-Media has become more and more clearly in front of us. With the development of Internet communication technology and the degree of information technology to upgrade, BBS, podcast, blog, micro-blog, We Chat and other media platforms began to emerge in large numbers, through these platforms numerous individual communicators spread with the subjectivity, randomness, universal purpose of text, sound or image and other information at any time on the internet .Information can be quickly spread among many free communicators, this has led to a rapid rise in the influence of We-Media.

\section{The Influence of We-Media on College Teaching}

Colleges and universities have the youngest among the society and the most liberal groups_college students. With the rapid development of the We-Media encountered such a special group, its large energy spurt out. College student hardly refuse any emerging We-Media application, from the BBS to the blog, podcast, to micro-blog, and now We Chat, the constantly updated We-Media truly fully into every life of College Students.

Obviously, the modern school has been deeply influenced by the We-Media. We-Media has been laid a huge user base in the college population with good user response, apparently in the lives of teachers and students cannot do without the media, the We-Media will be integrated into the curriculum of higher education is imperative in fact. Teachers and students are likely to bring all kinds of information into the classroom through the We-Media, which will impact the educational 
science and thought. Correct media information can enrich the knowledge of teachers and students, at the same time, false media information may mislead teachers of teaching and student learning. Therefore, teachers must use the We-Media correctly and effectively, promote the development of university teaching, stimulate students' interest in learning, to mobilize students' enthusiasm for learning and cultivate more high-quality talents.

\section{Strategies of Teaching Reform of GIS Course in Colleges and Universities at the We-Media Time}

In recent years, GIS curriculum teaching in Colleges and universities has been walking on the road of reform and innovation, facing the strong impact of the media and the new changes in education, to make the GIS classroom teaching really effective, we must carry out the reform of the system, and comprehensively promote the reform and innovation of teaching mode.

GIS Theory Curriculum Reform Strategy under the Background of We-Media. GIS courses in Colleges and universities in the classroom teaching content should be close to the times, close to the students, the students are concerned about, and the course of the network hot spots and difficult problems should be timely response and answer, highlighting the course content of the fresh activity. Rich media content and diversity, is an excellent education and teaching resources, teachers in the classroom teaching should be in a timely manner to the network resources to the classroom teaching.

In the We-Media environment, the popularity and convenience of the Internet and mobile phone has become a new culture carrier, and gradually show its unique advantages. The GIS class should make full use of its intuitive, convenient, real-time, can participate in, without the limitation of time and space characteristics of teaching. The main channel to acquire knowledge and information on the students in the traditional classroom teaching effect has been seriously weakened, when BBS, renren.com, micro-blog, WeChat and other media to occupy the students get in by every opening time, exerts a subtle influence on students' ideology, value judgment and behavior choice. The University GIS teaching must take the initiative to capture this idea position.

Teachers can build web blog teaching information release, upload pictures, animation, video and other teaching materials for students to learn, to promote interactive communication; through the establishment of the QQ group, QQ group discussion, micro public, Internet chat rooms and other online classroom, upload information, information release, discussions etc. By making the micro course design, teaching case, new teaching form flipped classroom curriculum to expand and extend the network to the extension of the extent of the use of cyber source to enhance the effect and means of cultivating and improving students' autonomous learning ability, research ability, cognitive ability and learning level.

The use of media and media space to design online operations is also a rich way of teaching form. The barrier free media communication mode, which brings the unprecedented influence and challenge to the classroom teaching of GIS course in University, has brought the unprecedented opportunity for its reform and innovation. It makes the content of classroom teaching, the carrier, means more rich, more makes the network classroom construction possible, has greatly enriched the classroom teaching the carrier and the form. In teaching, as long as teachers can change ideas, work together, and actively take effective strategies, and constantly innovate methods, it will make the GIS theory of college students' radiate new vigor and vitality under the We-Media conditions.

Through the media platform editing course teaching materials, production course teaching scene. Can first use of its media properties better the teaching content, the kind of information into the teaching; secondly, with the development of the times, our teaching content is always in continuously updated, traditional teaching, lesson plans often require something a long time to update a, the students often in the textbooks to school to is old knowledge, the use of media platform to edit the contents of the can in a timely manner to supplement or modify, can make up the teaching material lag.

For example, we can rely on the micro channel micro channel scene features, it can be made similar to the effect of the multimedia courseware, students can through reading of teacher 
curriculum making micro channel scenes to reach a near the effect of multimedia teaching. Outside of the classroom teaching, students often have some problems according to the classroom knowledge to extend thinking produced, then the teacher in understanding can through the microblogging way to publish the relevant knowledge of their students to check, can even record a video lecture to upload, so as to a student to answer queries at the same time, let more students can also see the problem, check whether they had the same question or to consolidate their professional knowledge. Students can also through the microblogging comments on the question of mutual discussion may be more inspired.

Using We-Media to Establish the Practice Platform of GIS Curriculum in Colleges and Universities. Construction on the teaching mainly, supplemented by We-Media teaching GIS practice teaching platform, construction of a number of to practice project named public media, and the teacher responsible for the care of the, and students care about each other, release of information processing, question answering and asked students to practice the project after the completion of the pictures published, give timely guidance and evaluation. Evaluation of these will eventually be included in the curriculum for students' grades. As shown in Fig. 1.

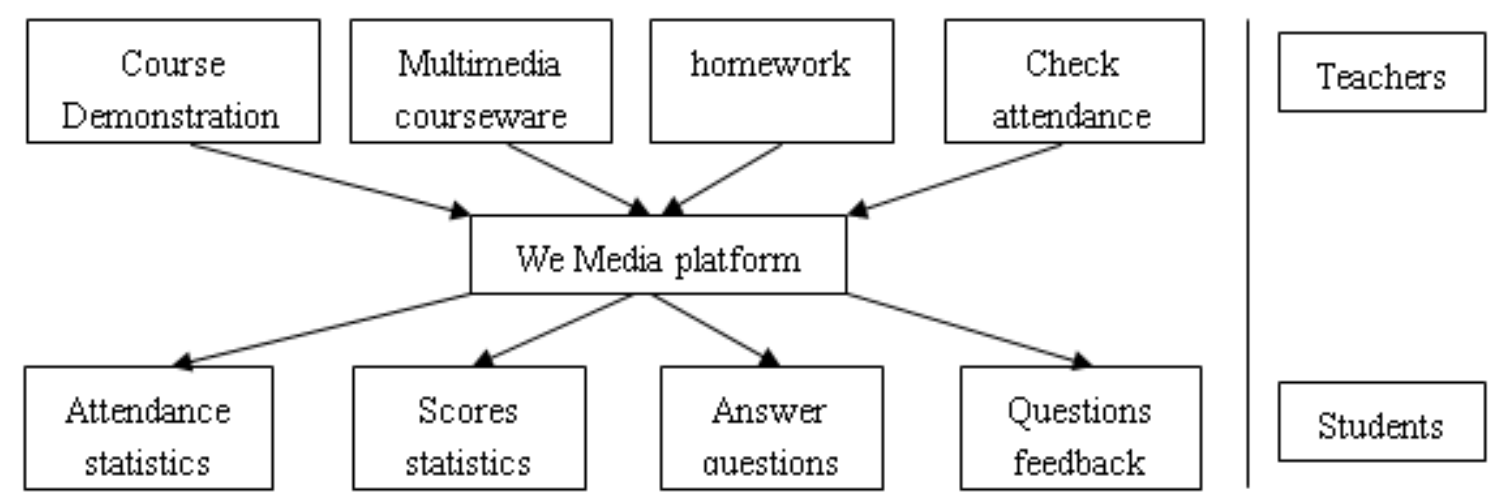

Figure. 1 Application of We-Media platform model

In addition to set up a public platform, the teachers are encouraged to set up their own media platform, outside of the classroom they and students can establish stable and effective network connection, the formation of new relationship between teaching and learning and building a harmonious relationship between teachers and students has a good role in promoting

Due to the radioactive characteristics of media mode of transmission, in order to ensure the fairness of the media platform, open and authenticity, the supervision of the media platform is especially important. We-Media public number of responsible person to effectively assume supervision duties, through the platform release information, in addition to ensure the true accuracy of the information, but also at any time to pay attention to the student's media accounts from the media and the state of speech, the establishment of active, healthy and equal practice of the exchange of We-Media platforms.

\section{Conclusion}

In the rapid development of GIS education, the rapid spread of the We-Media today, the university should be combined with the characteristics of the school of Surveying and mapping engineering major, to make teaching reform, and constantly improve and improve the GIS teaching of Surveying and Mapping Engineering, teachers should keep pace with the times, emancipate the mind, forge ahead, and constantly explore new ways of teaching reform from the media era, to improve the teaching level of GIS courses. At present, the application of the media in the teaching of Surveying and mapping major GIS course in Colleges and universities is still in the initial exploration stage, it still requires colleges and universities across the country according to its own characteristics explore actively, it also needs to strengthen cooperation and exchanges between 
colleges and universities, only in this way can colleges and universities seize the new opportunities of development, and effectively promote the construction and reform of GIS courses.

Discipline construction is vital to the development of professional .In the future social development process, if GIS professionals want to play its due role, further development, colleges and universities must build scientific and reasonable GIS system of discipline construction. Making its development more and more perfect, the training of talents more able to adapt to the development of the society.

\section{References}

[1] Liu Feng. Teaching exploration and practice of GIS course[J].Journal of Changsha Social Work College, 2010,17(3):93-94

[2] Zhou Ying, Zhao Zhiwei. Research the discipline construction of GIS major from the perspective of the development of Surveying and mapping [J]. Education Research. 2015(60):264-264

[3] Yao Wanqiang, Li Chonggui, Ma Qingxun, Qiu Chunxia, Hu Rongming. Research on the teaching and educational reform of geographic information system [J]. Technology and Innovation Management,2011,32(2): 2011, 32(2):195-198

[4] Jiang Youyi. Discussion on the teaching of GIS course in surveying and mapping engineering in colleges and universities[J].Technology and Innovation Management,2012,33(5): 2012, 33(5):591-594

[5] Ye Zhenglong, Sun Xuchang. Exploration and thinking about the application of We-Media in the teaching of higher education[J].Journal of Jingdezhen University, 2015(5):121-124

[6] Mei Xiaodan, Wang Yanliang, Ma Junhai. Research and practice of GIS teaching system of Surveying and Mapping Engineering Based on "excellent plan"[J]. Engineering of Surveying and Mapping, 2013, 22(5):93-96

[7] Yao Jing, Liu Yumei, Sun Lishuang, Wang Zin. Discussion on teaching reform of Surveying Course for non-surveying and mapping major in Civil Engineering [J]. Education and Teaching Forum. 2012(37):121-122

[8] Hu Honglin. Research on geography teaching strategy under the background of media [J].Educational Research. 2015(26):212-213

[9] $\mathrm{Wu}$ Yandong. Teaching reform and innovation strategy of Ideological and political theory course in Colleges and universities from the media era $[\mathrm{J}]$. Journal of Daqing Normal University, 2015,35(6):116-118

[10]Chen Qibo, Wang Jing, Zhou Aiju, Song Jianhua. Application of We-Media in design experiment teaching[J].www.gdchem.com, 2015(13):277-278 